\title{
Work-related injuries among farmers: a cross-sectional study from rural Nepal
}

\author{
Devendra Bhattarai ${ }^{1}$, Suman Bahadur Singh ${ }^{2 *}$, Dharanidhar Baral ${ }^{1}$, Ram Bilakshan Sah', \\ Shyam Sundar Budhathoki $i^{1}$ and Paras K. Pokharel ${ }^{1}$
}

\begin{abstract}
Background: Agriculture work is one of the most hazardous occupations across countries of all income groups. In Nepal, $74 \%$ of people are working in the agricultural sector. This study aims to identify patterns and factors associated with injuries among farmers of rural Nepal.

Methods: A community-based cross-sectional study was conducted in a rural village in eastern Nepal. House to house visit was done to collect data from the farmers. The study included 500 farmers from Shanishchare village in Morang district of Nepal. A pre-tested semi-structured questionnaire was used to collect data on socioeconomic profile, agriculture work and injury. Prevalence of injuries among farmers in the last 12 months was calculated along with factors associated with the injuries.

Results: The overall prevalence of work- related injuries among farmers was $69 \%$ in the last 12 months. Common injuries among the farmers were cuts (79.7\%), puncture wound (11.3\%) and laceration (7.5 \%). Hand tools were responsible for most of the injuries followed by slipping at work, sharp instruments, animals and fall from height. Upper limb injury comprised of $67 \%$ of all injuries and the most involved part was fingers (43\%). The average number of years worked in farming by the respondents was $23.6 \pm 13.6$ years. Age and working experience of the farmers was found to be significantly associated with the occurrence of injuries among the farmers.
\end{abstract}

Conclusions: The prevalence of injury among farmers in this study was high. Further research is needed to identify interventions to reduce the agricultural injuries in Nepal.

Keywords: Occupational Health, Farmers, Injuries, Rural Nepal

\section{Background}

About 350,000 deaths occur globally due to fatal occupational injuries [1,2]. The vulnerable population of South East Asian countries comprising of women, the poor, and children, are primarily employed in the informal sectors. They often lack the basic knowledge of hazards and work for long hours in unsafe work conditions without personal protection at work and with little or no health care insurance [3]. The use of machineries and equipment have led to newer occupational injuries among these workers $[4,5]$.

Agriculture has traditionally been one of the most hazardous occupations for workers [6, 7]. Agricultural

\footnotetext{
* Correspondence: sumanbahadur.singh@bpkihs.edu

${ }^{2}$ Lifeline Institute of Health Sciences, Damak, Nepal

Full list of author information is available at the end of the article
}

sector provides a strong foundation for rural economic and for the sustainable economic growth [8]. An estimated 1.3 billion workers are engaged in agricultural production worldwide. This represents half of the total world labour force, and almost $60 \%$ of them are in developing countries [9]. Agricultural injuries are reported from all around the globe [10-14].

In Nepal, agriculture contributes to $39 \%$ of the gross domestic product with $13 \%$ of the total foreign trade. Keeping in view of this contribution, priority is given to the development of the agriculture sector in the Eighth Five Year Plan [15]. In Nepal, $73.9 \%$ of people are working in the agricultural sector and $26.1 \%$ in non-agriculture [16]. The intensive use of machinery has raised the risks of injuries [17]. Musculoskeletal injuries are the predominant form of reported non-fatal occupational injuries. Fractures, 
bruises, lacerations, contusions, penetration by foreign bodies and sprains or strains are the most frequent type of occupational injuries [17-19].

\section{Occupational safety and health in Nepal}

Approximately 20,000 work related accidents are estimated to occur every year and 200 lives are lost each year in Nepal due to work related injuries and accidents [20]. Occupational safety and health in Nepal is in its primitive stage [21]. Occupational safety and health has received limited attention by the health sector in Nepal $[20,22,23]$. The existing labour law has a small portion where the safety and health is a brief section with vague provisions for overall health and welfare of workers. The act has highlighted only four occupations; tea estate, construction, transportation and hotel \& tourism sector separately. The law seems to focus only on increasing productivity rather than health and safety [21, 24]. Limited research is found in occupational safety and health and no research was found focusing on injuries among farmers [23]. Use of personal protective equipment (PPE) among farmers is not known and is reported low in other occupations [22].

Farmers are working under unsafe conditions, particularly in low income countries, leading to injury and death. Farmers are at risk for injury because agricultural work involves multiple tasks and multiple locations. Most of the tasks are carried out in the open air, exposing the workers to adverse working conditions. The majority of farmers are informal sector workers. Farming in villages is a householdbased owned occupation and not a company owned business in Nepal. Literature searches in Pubmed, Google scholar and Nepal journal online resulted in the limited literature on injuries among farmers in Nepal. In Nepal there is no systematized recording and reporting of agricultural injuries. Data on injury at national level is also inadequate. This study was conducted to identify patterns of agricultural injuries and assess the factors associated with work-related injuries among agricultural farmer in rural Nepal.

\section{Methods}

Morang district is the largest rice producer district of Nepal [25]. Shanishchare village was chosen randomly using the lottery method out of the 65 villages of Morang district. A community based cross-sectional study was carried out among farmers of the Shanishchare village in the eastern region of Nepal. This village is a highly populated village with a population of 29,804 and 5490 households, according to the population census of 2011. Based on the village data, agriculture work is the primary occupation of $19 \%$ of the households in Shanishchare [26].
The sample size was calculated using the prevalence of work-related injuries among farmers, [10] in Hubei, People's Republic of China. Taking prevalence of $33 \%$ from this study and margin of error, as $15 \%$ of prevalence, the sample size was calculated using the formula.

Sample size $(n)=\mathrm{Z}^{2} \mathrm{pq} / \mathrm{L}^{2} \quad n=\left(1.96^{2} * 33 * 67\right) / 4.35^{2}$ (where $\mathrm{L}=15 \%$ of $\mathrm{p}$ ) $\{\mathrm{Z}=1.96 ; p=33 \%$; $\mathrm{q}=$ compliment of p\} $n=449$.

Adding $10 \%$ sample to correct non response, our expected sample size was decided as 494. Thus, we invited 500 farmers from the Shanishchare village to participate in this study.

Our Study period was from September 2012 to December 2013 which included the protocol designing, ethical approval, data collection and report preparation.

Farmers $\geq 20$ years of age, having agricultural land $\geq 5$ Katthas ( 1 Kattha $=3645$ square feet), who worked in their own farm in Shanishchare village were included in our study. Farmers who are from Shanishchare village and working in fields outside Shanishchare village or farmers from other villages working on farms in Shanishchare village were excluded from our study. The reason for the exclusion of these farmers is that since farmers who work on other people's land are more mobile and seasonal working for wages, or change occupation frequently, it is not feasible to include them in the study as well as disseminate the study findings afterwards. As per the Village Development Committee (VDC) office, there were 2500 farmers having land $\geq 5$ Katthas for cultivation in Shanishchare. After the list of the 2500 farmers was obtained from VDC office, 500 farmers were selected using Systematic Random Sampling selecting every fifth farmer from the list. The first farmer was selected by generating a computer generated random number. However, some information bias cannot be avoided as the farmers were interviewed about injuries in the last 12 months, which is prone to some recall bias. We approached their home to conduct the interviews. If they were not present, we returned after arranging an appointment.

Socio demographic characteristics, work related data and injury characteristics were collected using a semistructured questionnaire prepared by a team comprising of a Senior Public Health researcher, two Occupational Physicians, an Environmental health expert, a Biostatistician and a Master in Public Health student. The Semistructured questionnaire was pretested among 50 farmers of Bayarban village, adjacent to Shanishchare village.

Working duration of the farmers was categorised taking $48 \mathrm{~h}$ as a cut off for working hours per week; and 20 years as cut off for years of working experience in this study. Both of these are based on the working duration criteria of the Labour Act of Nepal. The act states that the maximum number of working hours in a week should not exceed $48 \mathrm{~h}$ in occupation. It has provision 
of retirement from work after completion of 20 years in any occupation [24].

The collected data were checked thoroughly for completeness and entered in excel sheet after coding the data for analysis. Data Analysis was done using Statistical Package for Social Sciences (SPSS) version 11.5. Frequency and percentages are used to express descriptive statistics. Bivariate analysis of categorical data was done using $\mathrm{X}^{2}$ test. Unadjusted Odds Ratio was calculated using Epi info 7. We calculated the $95 \%$ confidence interval and the probability of significance was set at $5 \%$.

\section{Results}

All 500 respondents approached for the study participated in this study giving a response rate of $100 \%$. The mean age of the respondents was $43.6 \pm 13.2$ years. There was an equal representation of male and female farmers in this study. All respondents in this study owned their own land for farming. The socio-demographic characteristics of the farmers in this study are shown in Table 1.

The average number of years worked in farming by the respondents was $23.6 \pm 3.6$ years. More than 3/5th of the respondents, did not use any Personal Protective Equipment (PPE) at work. Among those who use PPE, $97.14 \%$ use ordinary cotton mask, $4 \%$ use boots and $1.7 \%$ use gloves at work (Table 2).

Table 1 Socio-demographic characteristics of farmers in Shanishchare village $(n=500)$

\begin{tabular}{lllc}
\hline Characteristics & Categories & Number & Percentage (\%) \\
\hline Age & $<30$ years & 79 & 15.8 \\
& 30-39 years & 121 & 24.2 \\
& 40-49 years & 122 & 24.4 \\
& $50-59$ years & 107 & 21.4 \\
& $\geq 60$ years & 71 & 14.2 \\
Gender & Male & 246 & 49.2 \\
Marital status & Female & 254 & 50.8 \\
& Single & 57 & 11.4 \\
Religion & Married & 443 & 88.6 \\
& Hindu & 366 & 73.2 \\
& Buddhist & 25 & 5.0 \\
& Kirant & 97 & 19.4 \\
Literacy & Christian & 12 & 2.4 \\
Types of family & Illiterate & 86 & 17.2 \\
& Literate & 414 & 82.8 \\
Land holding & Nuclear & 242 & 48.4 \\
& Joint & 258 & 51.6 \\
& $\leq 15$ Kattha & 287 & 57.4 \\
\hline
\end{tabular}

Table 2 Working characteristics of the respondents $(n=500)$

\begin{tabular}{lllc}
\hline Characteristics & Categories & Number & Percentage (\%) \\
\hline Working hours & $\leq 48$ hours & 119 & 42.2 \\
& $>48$ hours & 324 & 57.8 \\
Work experience & $\leq 20$ years & 183 & 36.6 \\
& $>20$ years & 317 & 63.4 \\
Personal Protective & Yes & 175 & 35.0 \\
Equipment (PPE) use & No & 325 & 65.0 \\
Types of protective device & Ordinary Mask & 170 & 97.2 \\
$(n=175)^{\mathrm{a}}$ & Boot & 7 & 4.0 \\
& Gloves & 3 & 1.7 \\
\hline
\end{tabular}

${ }^{a}$ Multiple responses

A total of 345 respondents (69 \%) reported being injured in the past one year. Among these 345 respondents, 9 out of 10 respondents were injured more than once in the past 12 months (Table 3 ).

Hand tool was a frequent mode of injury among the respondents. Hand tools included sickle, axe, spade, hand saw and hoes. Most frequent types of injury were cut, and the site of injury was fingers (Table 4).

A total of $222(64.3 \%)$ injured workers took some time off work due to injury. The mean $( \pm \mathrm{SD})$ number of days lost due to injuries was $11.4 \pm 9.6$ days. Out of 345 injured respondents, 245 (71\%) of them used local herbs for first aid treatment. There were $233(67.5 \%)$ injured farmers who went to the health institution for wound treatment. Apart from herbs, human urine, mud, warm oil and toothpaste were used for first aid treatment of the injury. (Not shown in tables)

The association between socio-demographic characteristics and injuries among farmers is displayed in Table 5.

Table 3 Injury related characteristics reported by respondents $(n=345)$

\begin{tabular}{lllc}
\hline Characteristics & Categories & Number & Percentage (\%) \\
\hline Environment where injured & Working field & 314 & 91.0 \\
& On the way & 19 & 5.5 \\
& House & 12 & 3.5 \\
Frequency of injuries & One time & 37 & 10.7 \\
(in past one year) & Two times & 161 & 46.7 \\
& Three times & 121 & 35.1 \\
& More than & 26 & 7.6 \\
Season when injured & three times & & \\
& Rainy season & 221 & 64.1 \\
Time when injured & Winter season & 124 & 35.9 \\
& Morning & 107 & 31.0 \\
& Day & 209 & 60.6 \\
& Evening & 29 & 8.4 \\
\hline
\end{tabular}


Table 4 Mode of injury, type of injuries and body parts injured $(n=345)$

\begin{tabular}{lllc}
\hline Characteristics & Categories & Frequency & Percentage (\%) \\
\hline Mode of injury & Hands tools & 258 & 74.7 \\
& Slipping & 29 & 8.4 \\
& Animals & 27 & 7.8 \\
& Sharp instruments & 23 & 6.7 \\
& Fall & 8 & 2.3 \\
Types of injuries & Cuts & 275 & 79.7 \\
& Punctures & 39 & 11.3 \\
& Laceration & 26 & 7.5 \\
& Fracture & 5 & 1.4 \\
Body parts injured ${ }^{\mathrm{a}}{ }^{2}$ & Finger & 151 & 43.8 \\
& Leg & 105 & 30.5 \\
& Hand & 70 & 20.3 \\
& Head & 23 & 7.9 \\
& Knee & 15 & 4.2 \\
& Trunk & 8 & 2.3 \\
& Eye & 5 & 1.4 \\
\hline
\end{tabular}

${ }^{\mathrm{a}}$ Multiple responses

\section{Discussion}

While there are only limited hospital or community based studies on injuries of all kinds in Nepal, no published literature was found regarding injuries among farmers in Nepal $[27,28]$. This study could provide some evidences for further studies on agricultural injuries in Nepal. All the farmers owned their own land for farming in this study. However, it is a practice to work for another farm owner during need which is paid back by contributing equal number days in each other's farm. This study showed that the majority of the farmers belonged to age group of 40-49 years, accounting for $24.4 \%$ of all farmers. In this study, the mean age $( \pm S D)$ was found to be $43.6 \pm 13.2$ years, which was similar to the findings of other studies [10-12, 29]. A crosssectional study in India reports mean age $( \pm S D)$ of farmers as $31.9 \pm 6.6$ years, which is much younger compared to our study [30]. Higher proportion of the injuries occurred among farmers in the age group 40-49 years. Another cross-sectional study in India shows high injury among farmers in the same age group as our study [31]. However, other studies show injuries among farmers in younger age groups [32]. This is explainable as the farmers in our study are comparatively older compared to the farmers in other studies. The overall prevalence of work- related injuries among farmers injury was $69 \%$ in the last 12 months. Similarly, a cross-sectional study among agricultural workers in Ethiopia showed markedly high rates of injuries [11]. Both Nepal and Ethiopia
Table 5 Distribution of association between Socio- demographic characteristics of farmers by injuries in last one year in Shanishchare village

\begin{tabular}{|c|c|c|c|c|c|}
\hline \multirow[t]{2}{*}{ Characteristics } & \multicolumn{2}{|c|}{ Accidents in last one year } & \multirow[t]{2}{*}{$p$-value ${ }^{a}$} & \multicolumn{2}{|c|}{$\begin{array}{l}\text { Unadjusted } \\
\text { Odds Ratio }\end{array}$} \\
\hline & Yes $(n=345)$ & No $(n=155)$ & & $\mathrm{OR}$ & $95 \% \mathrm{Cl}$ \\
\hline \multicolumn{6}{|l|}{ Age in years } \\
\hline$<30$ & 35 & 44 & 0.001 & 1 & \\
\hline $30-39$ & 86 & 35 & & 3.08 & $1.70-5.58$ \\
\hline $40-49$ & 86 & 36 & & 3.00 & $1.66-5.41$ \\
\hline $50-59$ & 87 & 20 & & 5.46 & $2.83-16.56$ \\
\hline$\geq 60$ & 51 & 20 & & 3.20 & $1.62-6.33$ \\
\hline \multicolumn{6}{|l|}{ Gender } \\
\hline Male & 162 & 84 & 0.134 & 1 & \\
\hline Female & 183 & 71 & & 1.33 & $0.91-1.95$ \\
\hline \multicolumn{6}{|l|}{ Marital status } \\
\hline Single & 27 & 30 & 0.001 & 1 & \\
\hline Married & 318 & 125 & & 2.82 & $1.61-4.34$ \\
\hline \multicolumn{6}{|l|}{ Literacy } \\
\hline Literate & 279 & 135 & 0.088 & 1 & \\
\hline Illiterate & 66 & 20 & & 1.59 & $0.92-2.74$ \\
\hline \multicolumn{6}{|l|}{ Type of Family } \\
\hline Nuclear & 163 & 79 & 0.441 & 1 & \\
\hline Joint & 182 & 76 & & 1.16 & $0.79-1.69$ \\
\hline \multicolumn{6}{|c|}{ Working hours ( per week) } \\
\hline$\leq 48$ hours & 127 & 84 & 0.001 & 1 & \\
\hline$>48$ hours & 218 & 71 & & 2.03 & $1.38-2.98$ \\
\hline \multicolumn{6}{|c|}{ Working experience (years) } \\
\hline$\leq 20$ years & 159 & 98 & 0.001 & 1 & \\
\hline$>20$ years & 186 & 57 & & 2.01 & $1.36-2.96$ \\
\hline
\end{tabular}

${ }^{a} x^{2}$ test

are developing countries and are agrarian based and thus similar scenario can be seen. In Ethiopia, agriculture holds $41 \%$ contribution to the gross domestic product, which is similar in Nepal, where agriculture contributes a similar proportion to the gross domestic product [16]. A study from India (30.6\%) shows a lower prevalence of agricultural injury compared to our study [33]. Incidence of injury among the farmers was lower in high income countries $[34,35]$. The injuries among farmer are higher in low income countries compared to middle and high income countries. A case series study of surgical trauma and associated head injuries attending to a tertiary hospital in Nepal, reports one fifth of the injured patients were farmers [27]. A study of injury in an urban area of Nepal highlights that farmers suffered more injuries compared to workers in other occupations [28]. 
Out of 345 injured farmers, a large proportion of respondents $(91.0 \%)$ pointed farming fields as a spot for injury occurrence. Our study reported more frequent injuries compared to Ethiopia. Though Ethiopia is a low income country like Nepal, the use of machineries in farming and the techniques of farming may be different, which could explain the difference in findings [11].

One third of the farmers in this study report that they use personal protective equipment (PPE), however, almost all of these farmers only use ordinary masks at work, which they consider as PPE to be used in farming. This is a huge gap identified in our study. Use of PPE seems a neglected issue among farmers. They are not aware of any PPE required for farm work. Further researches may be needed to explore ways to increase access and the use of PPE by farmers.

Hand tools are the most frequent cause of injury in this study. The findings are similar in Indian farmers as well [30]. As a neighbouring country, the contexts of Nepal and India are comparable in population, culture, technology and practices. The findings are similar to the farmers from other countries [10, 11, 27, 36, 37]. Hand equipment like sickles and spades are still used routinely in the farms in Nepal. Cutting of grass, rice, wheat weeding, ridge formation, harvesting and irrigation channel making are done manually. This could explain hand tools as a major mode of injury in this study.

The most common types of injuries among farmers were cuts, puncture and laceration. Similar injuries were reported about Ethiopian farmers [11]. Popularity of traditional mechanical tools and not practicing safety measures could explain the prevalent injuries among the farmers.

Injuries were more common in hands than other parts of the body in this study similar to the study from Ethiopia [11]. Regular involvement of the fingers and hands in activities like cutting of grass and crops during working hours might increase risk of injury among them. Further, lack of safety precaution like use of personal protective equipment could put the farmers at more risk for injury.

There is similar proportion of males (49.2\%) and females (50.8 \%) involved in agricultural activities. This highlights that women of Nepal are actively involved in agricultural activities besides regular household chores. National data of Nepal show slightly higher proportion $(60 \%)$ of women's involvement in agriculture [20]. However, there is no significant difference in injuries among male and female farmers. Farm related injuries in Ethiopia showed that majority of study participants (77.8 \%) were males [11]. Multiple studies report injuries among male farmers are more during farming [4, 38]. This could be explained as males are more involved in farming compared to females.
Comparable to the findings from Ethiopia, illiterate farmers were injured more than the literate farmers in this study $[11,15]$. Further exploration may be needed as to why illiterate farmers have more injuries.

Farmers who worked for less or equal to $48 \mathrm{~h}$ a week, were less injured compared to those who worked for more than $48 \mathrm{~h}$ per week. Possible explanation could be that the farmers who work for more hours they will spend more hours exposed to the risk factors for injuries. The finding is similar in Ethiopian farmers [11].

There was a significant association between injury and the number of years worked as farmers. Similar findings were reported from Ethiopia [11]. This finding suggests that there may be a tendency of farmers to be less careful at work if they have worked for many years. This may also need further exploration.

Traditional practices are being practiced for first aid for injuries. This highlights the deep rooted traditional practice in our society. Local herbs are used for first aid and many do not visit a health institution at all. Injuries at work are perceived minor by these farmers. Traditional practices are also reported from India, where urination on wounds are practiced, as first aid [27]. Application of mud or cow dung on the injury site has been reported [33]. This shows that the farmers seem to lack skills and probably any knowledge about basic first aid.

\section{Limitations}

The age and land ownership criteria for inclusion in this study may have left out daily wage seasonal agricultural labourers. The seasonal labourers are more migratory and they change working setup from agriculture to construction or other physical labour demanding works based on the availability of opportunities. Interviewing of only one farmer per land parcel may have left out the injury data on other workers in the family from the same farm. Only persons available at the time of study were included and we could not include the farmers who were not at home. There is possibility of recall bias in history of injury for last 12 months. The study could not identify a causal association for injuries at work among farmers. Other workers on the farm and the non-owners farm workers are not represented by this study. We have further plans to build on the findings of this research to conduct further research to address these farm workers.

\section{Conclusion}

The most common types of injury among farmers were cuts, puncture and laceration. Most of the agricultural work is mechanical and farmers are found to be using traditional hand tools in Nepal. Laborious work, maximum use of hand tools, challenging work environment and neglecting safety measures could be responsible for occupational injury. While literatures are scanty in Nepal, 
this study provides evidence regarding injuries faced by farmers in Nepal, a country whose primary occupation is agriculture. Farming related stakeholders at village level, the agriculture administration at the local and national level, policy makers and researchers could use the findings of this study to design further studies to identify appropriate interventions to decrease injuries among farmers and address the occupational health needs of the farmers in Nepal.

\section{Abbreviations \\ PPE: Personal protective equipment; SPSS: Statistical Package for Social Sciences; VDC: Village Development Committee}

\section{Acknowledgements}

We acknowledge the cooperation of all the participants of the study.

\section{Funding}

None.

\section{Availability of data and materials}

All data generated or analysed during this study are included in this published article.

\section{Authors' contributions}

DB was involved in conception \& designing of the study, data collection, analysis, draft writing \& final version preparation for publications. SBS was involved in designing of the research, interpretation of data, drafting of manuscript and preparing the final version for publication. DB was involved in designing of the research, data analysis, manuscript revision and preparing the final version for publication. RBS was involved in conceptualizing the research, manuscript revision and preparing the final version for publication. SSB was involved in conceptualizing the research, interpretation of data, preparing draft and revising it for intellectual content and preparing the final version for publication. PKP was involved in conceptualizing the research, interpretation of data, revising the draft manuscript \& approving the final version of the manuscript for publication. All authors read and approved the final manuscript.

\section{Authors' information}

DB is a MPH graduate working as a lecturer at the Lifeline Institute of Health Sciences, Nepal.

SBS is a Community Physician working in Occupational Health Unit at School of Public Health \& Community Medicine, B P Koirala Institute of Health Sciences, Dharan, Nepal. SBS holds an academic post of Additional Professor. DB is a Statistician and Research Methodologist at the School of Public Health \& Community Medicine, B P Koirala Institute of Health Sciences, Dharan, Nepal. SBS holds an academic post of Assistant Professor.

RBS is Community Physician working in Environmental Health unit at the School of Public Health \& Community Medicine, B P Koirala Institute of Health Sciences, Dharan, Nepal. RBS holds an academic post of Associate Professor.

SSB is a Community Physician cum Public Health Professional working in Occupational Health unit at the School of Public Health \& Community Medicine, B P Koirala Institute of Health Sciences, Dharan, Nepal. SSB holds an academic post of Assistant Professor.

PKP is a senior Community Physician working as Professor of Public Health at the School of Public Health \& Community Medicine, B P Koirala Institute of Health Sciences, Dharan, Nepal.

\section{Competing interests}

The authors declare that they have no competing interests.

\section{Consent for publication}

Not applicable.

\section{Ethics approval and consent to participate}

Ethical clearance for the study was obtained from the Institutional Review Committee of the B P Koirala Institute of Health Sciences, Dharan, Nepal.
Each farmer was approached for a face to face interview at their home. Verbal consent was obtained before collecting data from the selected for our study. The interview lasted for 30-45 min.

\section{Data sharing statement}

No additional data are available.

\section{Author details}

${ }^{1}$ School of Public Health and Community Medicine, B P Koirala Institute of Health Sciences, Ghopa 18, Dharan, Nepal. ${ }^{2}$ Lifeline Institute of Health Sciences, Damak, Nepal.

Received: 11 June 2016 Accepted: 13 October 2016

Published online: 26 October 2016

\section{References}

1. Takala J. Introductory Report: Decent Work-Safe Work. XVIth World Congress on Safety and Health at Work. Vienna: International Labor Organization; 2005. p. 6-10.

2. Hämäläinen P. The effect of globalization on occupational accidents. Saf Sci. 2009;47(6):733-42.

3. World Health Organization. Regional Strategy on Occupational Health and Safety in SEAR counties [Internet]. New Delhi; 2005 [cited 2016 Feb 2]. Available from: http://apps.searo.who.int/PDS_DOCS/B0053.pdf. Accessed 2 Feb 2016.

4. Eijkemans G. Occupational Health \& Safety in Africa. African Newsl Occup Heal Saf. 2004;14:28-9.

5. Mohammed G. Ergonomics in small-scale grain mills in Nigeria. African Newsl Occup Heal Saf. 2005;15(1):7-10.

6. Crandall CS, Fullerton L, Olson L, Sklar DP, Zumwalt R. Farm-related injury mortality in New Mexico. Accid Anal Prev. 1997;29(2):257-61.

7. Frank AL, McKnight R, Kirkhorn SR, Gunderson P. Issues of agricultural safety and health. Annu Rev Public Health. 2004;25:225-45.

8. Economic JS, Analysis P. Second. Kathmandu: Taleju Prakashan; 2004.

9. International Labor Organization. Safety and health in agriculture [Internet]. International Labor Organization. Geneva; 2011 [cited 2016 Jan 9]. p. 1-350. Available from: http://www.lo.org/wcmsp5/groups/public/_ed_ dialogue/—sector/documents/normativeinstrument/wcms_161135.pdf. Accessed 9 Jan 2016.

10. Xiang H, Wang Z, Stallones L, Keefe TJ, Huang X, Fu X. Agricultural workrelated injuries among farmers in Hubei, People's Republic of China. Am J Public Health. 2000;90(8):1269-76.

11. Yiha O, Kumie A. Assessment of occupational injuries in Tendaho Agricultural Development S.C, Afar Regional State. Ethiop J Heal Dev. 2010; 24(3):167-74.

12. Pickett W, Hartling L, Brison RJ, Guernsey JR. Canadian Agricultural Injury Surveillance Program. Fatal work-related farm injuries in Canada, 1991-1995. Can Med Assoc J. 1999:160(13):1843-8.

13. Myers JR, Layne LA, Marsh SM. Injuries and Fatalities to U.S. Farmers and Farm Workers 55 Years and Older. Am J Ind Med. 2009;52(3):185-94.

14. Lee SJ, Kim I, Ryou H, Lee KS, Kwon YJ. Work-related injuries and fatalities among farmers in South Korea. Am J Ind Med. 2012;55(1):76-83.

15. Ministry of Agriculture Development. Welcome to Ministry of Agricultural Development [Internet]. Ministry of Agriculture Development, Government of Nepal. 2012 [cited 2016 Jan 3]. Available from: http://moad.gov.np/en/ content.php?id=319. Accessed 3 Jan 2016.

16. Central Bureau of Statistics. Report on Nepal Labor Force Survey 2008 Kathmandu; 2009 [cited 2016 Jan 3]. Available from: http://cbs.gov.np/ image/data/Surveys/2015/NLFS-2008\%20Report.pdf. Accessed 3 Jan 2016.

17. Levy BS, Wegman DH, Baron SL, Sokas RK. Occupational and Environmental Health: Recognizing and Preventing Disease and Injury. Sixth. Oxford: Oxford University Press; 2011

18. Fingerhut $M$, Driscoll $T$, Nelson DI, Concha-Barrientos $M$, Punnet $L$, Pruss-Ustin A, et al. Contribution of occupational risk factors to the global burden of disease - a summary of findings. Scand J Work Environ Heal Suppl. 2005;1:58-61.

19. Sprince NL, Zwerling C, Lynch CF, Whitten PS, Thu K, Gillette PP, et al. Risk factors for falls among lowa farmers: a case-control study nested in the Agricultural Health Study. Am J Ind Med. 2003;44(3):265-72.

20. Gautam RP, Prasain JN. Current situation of occupational safety and health in Nepal [Internet]. Kathmandu: General Federation of Nepalese Trade 
Unions (GEOFONT); 2011. [cited 2016 Jan 22]. p. 1-96. Available from: https://gefont.org/assets/upload/downloads/Study_OSH_Nepal.pdf.

21. Carter WS. Introducing occupational health in an emerging economy: a Nepal experience. Ann Occup Hyg. 2009:54(5):477-85.

22. Budhathoki SS, Singh SB, Sagtani RA, Niraula SR, Pokharel PK. Awareness of occupational hazards and use of safety measures among welders: a cross-sectional study from eastern Nepal. BMJ Open. 2014;4(6):e004646.

23. Joshi SK, Shrestha S, Vaidya S. Occupational safety and health studies in Nepal. Int J Occup Saf Heal. 2011;1:19-26.

24. Government of Nepal. Labour Act,2048 (1992). Nepal: Nepal Law Commission; 1992. p. 1-44.

25. Uprety R. System of Rice Intensification (SRI) Performance in Morang district during 2005 main season [Internet]. Biratnagar; 2005 [cited 2016 Aug 5]. p. 1-10. Available from: sri.ciifad.cornell.edu/countries/nepal/ nepuprety1205.pdf. Accessed 5 Aug 2016.

26. Central Bureau of Statistics. VDC Profile of Sanischare VDC, Morang District, Nepal. Kathmandu; 2011

27. Varghese $M$, Mohan D. Occupational injuries among agricultural workers in rural Haryana, India. J Occup Accid. 1990;12(1-3):237-44.

28. Ghimire A, Nagesh S, Jha N, Niraula SR, Devkota S. An epidemiological study of injury among urban population. Kathmandu Univ Med J. 2009;7(28):402-7.

29. Singh R, Sharma AK, Jain S, Sharma SC, Magu NK. Wheat thresher agricultural injuries: a by-product of mechanised farming. Asia-Pacific J Public Heal. 2005;17(1):36-9.

30. Das B. Agricultural work related injuries among the farmers of West Bengal, India. Int J Inj Contr Saf Promot. 2014;21(3):205-15.

31. Kumar GVP, Dewangan KN. Agricultural accidents in north eastern region of India. Saf Sci Elsevier Ltd. 2009;47(2):199-205.

32. Ohio Commission on the Prevention of Injury. Agriculture-Related Injuries [Internet]. Report from the Ohio Commission on the Prevention of Injury 2003. 2003 [cited 2016 Jan 23]. p. 1-13. Available from: http://www. publicsafety.ohio.gov/links/agriculture.pdf

33. Kalaiselvana G, Dongre AR, Mahalakshmy T. Epidemiology of injury in rural Pondicherry, India. J Inj Violence Res. 2011;3(2):62-7.

34. Lee K, Lim HS. Work-related injuries and diseases of farmers in Korea. Ind Health. 2008:46:424-34.

35. Maltais V. Risk Factors Associated with Farm Injuries in Canada 1991 to 2001. Ottawa; 2007. Report No.: 21-601. [Cited 2016 Jan 3]. Available from: http://publications.gc.ca/Collection/Statcan/21-601-MIE/21-601-MIE2007084. pdf. Accessed 3 Jan 2016.

36. Kumar A, Singh JK, Mohan D, Varghese M. Farm hand tools injuries: a case study from northern India. Saf Sci. 2008:46(1):54-65.

37. Mohan D, Patel R. Design of safer agricultural equipment: application of ergonomics and epidemiology. Int J Ind Ergon. 1992;10(4):301-9.

38. Bhandari GP, Dhimal M, Ghimire U. Epidemiological Study on Injury and Violence in Nepal [Internet]. Kathmandu; 2009 [cited 2015 Dec 10]. Available from: nhrc.org.np/files/download/0884f4dad42041c

\section{Submit your next manuscript to BioMed Central and we will help you at every step:}

- We accept pre-submission inquiries

- Our selector tool helps you to find the most relevant journal

- We provide round the clock customer support

- Convenient online submission

- Thorough peer review

- Inclusion in PubMed and all major indexing services

- Maximum visibility for your research

Submit your manuscript at www biomedcentral.com/submit

) Biomed Central 